\title{
PENERAPAN MODEL GROUP INVESTIGATION (GI) DALAM MENGIDENTIFIKASI CERPEN UNTUK MENINGKATKAN KEMAMPUAN MEMBACA SISWA PADA SDN 02 PALEMBANG
}

\author{
Dr.Sri Wahyu indrawati, M.Pd \\ Univ. PGRI Palembang \\ Email :Indrawatisriwahyu46@gmail.com
}

\begin{abstract}
Abstrak : Judul hasil penelitian ini adalah penerapan model group investigation (GI) dalam mengidentifikasi cerpen untuk meningkatkan kemampuan membaca siswa pada SDN 02 Palembang, rumusan masalah apakah pengaruh penerapan model group investigation (GI) dalam mengidentifikasi cerpen untuk meningkatkan kemampuan membaca siswa pada SDN 02 Palembang? Tujuan penelitian untuk mengetahui dan mendeskripsikan pengaruh penerapan model group investigation (GI) dalam mengidentifikasi cerpen untuk meningkatkan kemampuan membaca siswa pada SDN 02 Palembang. Populasi penelitian ini adalah seluruh siswa kelas V di SDN 02 Palembang. Sampel penelitian ini adalah kelas IIIa sebagai kelas eksperimen dan kelas IIIb sebagai kelas kontrol. Metode yang digunakan dalam penelitian ini adalah metode trueexperimental design. Teknik data yang digunakan adalah tes dan teknik wawancara. Dari hasil perhitungan statistik uji-t diperoleh $t_{\text {hitung }}=4,56$ dan $t_{\text {tabel }}=2,000$, dengan taraf signifikan $\alpha=$ 0,05. Dengan demikian berarti $t_{\text {hitung }}>t_{\text {tabel }}$, maka Ha diterima. Hal tersebut menunjukkan adanya pengaruh penerapan model group investigation $(G I)$ dalam mengidentifikasi cerpen untuk meningkatkan kemampuan membaca siswa pada SDN 02 Palembang.
\end{abstract}

Kata kunci : Group Investigation, kemampuan membaca dan cerpen

\section{PENDAHULUAN}

Pengajaran Bahasa Indonesia mempunyai ruang lingkup dan tujuan yang menumbuhkan kemampuan mengungkapkan pikiran dan perasaan dengan menggunakan bahasa yang baik dan benar. Sudah pasti pencapaian akademik diartikan sebagai pencapaian siswa dalam semua cakupan mata pelajaran. Evaluasi pencapaian akademik guru akan mengukur pencapaian hasil belajar siswa selama mengikuti proses pembelajaran.
Peneliti menetapkan SDN 02 Palembang sebagai objek atau tempat penelitian berdasarkan alasan: 1) siswa kelas III SDN 02 Palembang sudah mempelajari mengidentifikasi alur, penokohan, dan latar dalam cerpen yang dibacakan; 2) berdasarkan wawancara penulis dengan guru bahasa indonesia yang mengajar di kelas III di SD tersebut masih ada siswa yang belum mampu mengidentifikasi alur, penokohan, dan latar dalam cerpen; dan 3) berdasarkan pengamatan penulis, 
guru bahasa indonesia yang mengajar di kelas III di SDN 02 Palembang mendominasi kegiatan belajar mengajar dan guru sedikit sekali memberikan kesempatan siswa untuk terlibat aktif sehingga minat belajar siswa rendah.

Berdasarkan uraian di atas, peneliti tertarik untuk melakukan penelitian dengan judul, "Penerapan Model Group Investigation (GI) dalam mengidentifikasi Cerpen untuk Meningkatkan Kemampuan Membaca Siswa Pada SDN 02 Palembang".

Agar tidak terjadi penyimpangan dan tidak terlalu luas dari sasaran yang diharapkan dalam penelitian maka peneliti membatasi masalah ini Penerapan Model Group Investigation (GI) dalam mengidentifikasi Cerpen untuk Meningkatkan Kemampuan Membaca Siswa Pada SDN 02 kelas III di Kota Palembang. Rumusan masalah dalam penelitian ini adalah adakah pengaruh Penerapan Model Group Investigation (GI) dalam mengidentifikasi Cerpen untuk Meningkatkan Kemampuan
Membaca Siswa Pada SDN 02 Palembang.

\section{LANDASAN TEORI}

\subsection{Model Pembelajaran}

Mulyatiningsih

(2014:227) mengemukakan model pembelajaran merupakan istilah yang digunakan untuk menggambarkan penyelenggaraan proses belajar mengajar dari awal sampai akhir. Dalam model pembelajaran sudah mencerminkan penerapan suatu pendekatan, metode, teknik atau taktik pembelajaran sekaligus.

\subsection{Model Group Investigation}

Fathurrohman (2015:69) mengemukakan Group Investigation merupakan salah satu bentuk pembelajaran kooperatif yang menekankan pada partisipasi dan aktivitas siswa untuk mencari sendiri materi (informasi) pelajaran yang akan dipelajari melalui bahan-bahan yang tersedia.

\subsection{Tahap-Tahap Pembelajaran Model Group Investigation}

Tahap 1: Mengidentifikasikan Topik dan Mengatur Murid ke dalam Kelompok. 
Tahap 2: Merencanakan Tugas yang akan Dipelajari.

Tahap 3: Melaksanakan Investigasi.

Tahap 4: Menyiapkan Laporan Akhir.

Tahap 5: Mempresentasikan Laporan Akhir.

Tahap 6: Evaluasi.

\subsection{Pengertian Cerita Pendek}

Kosasih (2014:34) menjelaskan cerita pendek (cerpen) merupakan cerita yang menurut wujud fisiknya berbentuk pendek. Ukuran panjang pendeknya suatu cerita memang relatif. Namun, pada umumnya cerita pendek merupakan cerita yang habis dibaca sekitar sepuluh menit atau setengah jam. Jumlah katanya sekitar 500-5.000 kata. Karena itu, cerita pendek sering diungkapkan dengan cerita yang dapat dibaca dalam sekali duduk.

\subsection{Unsur-Unsur Intrinsik Cerpen}

Aminudin (2008:206)

menyatakan unsur-unsur intrinsik cerpen sebagai berikut.

(1) Alur, (2) penokohan, (3) latar, (4) tema, (5) amanat, (6) gaya bahasa,

(7) sudut pandang.

\subsection{Unsur-Unsur Cerpen}

Aminudin

(2008:209)

menyatakan unsur-unsur ekstrinsik cerpen sebagai berikut.

1) Keadaan subjektifitas pengarang yang memiliki sikap, keyakinan, dan pandangan hidup.

2) Psikologi pengarang (yang mencangkup proses kreatifnya) psikologi pembaca, dan penerapan prinsip-prinsip psikologi dalam sastra.

3) Keadaan di lingkungan pengarang seperti ekonomi, politik, dan sosial.

4) Pandangan hidup suatu bangsa dan berbagai karya sastra yang lainnya.

\subsection{Kajian Terdahulu yang Relavan}

Penelitian dengan menggunakan model Group Investigation ini pernah dilakukan oleh Padilah, mahasiswa universitas PGRI Palembang, tahun 2015 dengan judul skripsi, "Pengaruh model Group Investigation terhadap kemampuan siswa kelas III SDN 93 Palembang menentukan paragraf deduktif dan induktif. Padilah menyimpulkan 
bahwa terdapat pengaruh yang signifikan dari penerapan model Group Investigation terhadap kemampuan siswa kelas III SDN 93 Palembang menentukan paragraf deduktif dan induktif. Untuk itu dapat disimpulkan model pembelajaran Group Investigation efektif digunakan dalam pembelajaran.

\section{PROSEDUR PENELITIAN}

\section{Variabel Penelitian}

Adapun variabel dalam penelitian ini adalah sebagai berikut.

a. Variabel bebas (X) dalam penelitian ini adalah model Group Investigation.

b. Variabel terikat (Y) dalam penelitian ini adalah mengidentifikasi alur, penokohan, dan latar dalam cerpen yang dibacakan.

\section{Populasi Penelitian}

Sugiyono (2013:117) populasi adalah wilayah generalisasi yang terdiri atas: obyek/subyek yang mempunyai kualitas dan karakteristik tertentu yang ditetapkan oleh peneliti untuk dipelajari dan kemudian ditarik kesimpulannya. Berdasarkan pengertian tersebut, maka populasi dalam penelitian ini adalah seluruh siswa kelas III di SDN 02 Palembang tahun pelajaran 2019-2019 yang berjumlah 95 siswa.

\section{Sampel Penelitian}

Menurut

Arikunto (2014:174),"Sampel adalah sebagian atau wakil populasi yang diteliti”. Sedangkan, menurut Sugiyono sampel adalah bagian dari jumlah dan karakteristik yang dimiliki oleh populasi tersebut". Jadi, sampel adalah sebagian dari populasi yang diteliti. Sampel penelitian ini adalah siswa kelas III di SDN 02 Palembang tahun pelajaran 2018/2019. Pengambilan sampel penelitian ini menggunakan teknik cluseter sampling.

\section{Metode Penelitian}

Sugiyono (2014:3) menjelaskan metode penelitian dapat diartikan sebagai cara ilmiah untuk mendapatkan data dengan tujuan dan kegunaan tertentu. Penelitian dengan menggunakan pendekatan eksperimen bertujuan mencari pengaruh Penerapan Model Group Investigation (GI) dalam mengidentifikasi Cerpen untuk 
Meningkatkan Kemampuan

Membaca Siswa Pada SDN 02

Palembang. Dalam penelitian ini metode eksperimen yang digunakan adalah metode true experimental design yaitu Posttest Only Control Design.

\section{Teknik Pengumpulan Data}

Arikunto

menyatakan,'Tes adalah serentetan pertanyaan atau latihan suatu alat lain yang digunakan untuk mengukur keterampilan, inteligensi, kemampuan atau bakat yang dimiliki oleh individu (siswa) atau kelompok". Untuk mengukur kemampuan siswa kelas III di SDN Palembang dalam mengidentifikasi alur, penokohan, dan latar dalam cerpen yang dibacakan yang menggunakan model Group Investigation, penulis menggunakan tes tertulis.

\section{Arikunto}

$(2014: 198)$ mengemukakan,"Wawancara adalah sebuah dialog yang dilakukan oleh pewawancara untuk memperoleh informasi dari terwawancara". Teknik ini, penulis melaksanakan kepada satu orang guru bidang studi Bahasa Indonesia yang mengajar di kelas III di SDN 02 Palembang tahun pelajaran 2018/2019.

Sebelum tes diberikan kepada siswa sampel penelitian, penulis terlebih dahulu melakukan ujicoba kepada siswa sampel untuk menguji uji validitas dan uji realibilitas.

Sesuai dengan teknik pengumpulan data yang digunakan, maka teknik analisis data penelitian ini terdiri atas teknik analisis data tes siswa dan wawancara guru.

\section{HASIL PENELITIAN DAN PEMBAHASAN}

Penelitian ini dilakukan pada 2 kelas sampel, dimana dalam penelitian sampel menggunakan teknik Cluster sampling dalam teknik ini, random dilakukan atas dasar himpunan atau kelompok dengan tanpa mempertimbangkan besar atau kecilnya jumlah anggota sebuah himpunan atau kelompok, dimana kelas IIIa menjadi kelas eksperimen dan kelas IIIb menjadi kelas kontrol. Yang menjadi kelas eksperimen diajarkan menggunakan model pembelajaran Group Investigation dan sebagai kelas kontrol yang hanya diajarkan dengan menggunakan metode ceramah. 
Metode penelitian yang digunakan dalam penelitian ini adalah metode eksperimen Sedangkan jenis eksperimen peneliti menggunakan true experimental design dengan bentuk posttest only control design. Pemilihan penggunaan metode tersebut bertujuan untuk melihat pengaruh hasil belajar siswa pada kelas sampel. Peneliti mengharapkan adanya perbedaan antara hasil belajar siswa kelas eksperimen dengan siswa kelas kontrol.

Berdasarkan analisis data hasil tes kelas eksperimen yang menggunakan model pembelajaran Group Investigation dapat diketahui bahwa nilai rata-rata nilai post-test siswa kelas eksperimen yaitu kelas Va sebesar 84,41 dimana nilai tertingginya adalah 95 yang dapat diperoleh 5 orang siswa dan nilai terendahnya adalah 70 yang didapat oleh 2 orang siswa. Sedangkan untuk kelas IIIb sebagai kelas kontrol yang tidak menggunakan menggunakan model pembelajaran Group Investigation dapat diketahui bahwa nilai rata-rata post-test siswa sebesar 70,03 dimana nilai tertingginya adalah 90 yang didapat oleh 4 orang siswa dan nilai terendahnya adalah 50 yang didapat oleh 4 orang siswa. Hal tersebut menunjukan bahwa hasil belajar siswa dengan pembelajaran menggunakan model Group Investigation lebih baik daripada hasil belajar siswa yang menggunakan metode ceramah.

Dari hasil dari pembelajaran menggunakan model Group Investigation ini di kelas IIIa sebagai kelas eksperimen dapat dikatakan bahwa sebagian besar siswa dapat menerapkan model pembelajaran Group Investigation dalam kegiatan pembelajarannya, hal ini terbukti dari rata-rata post-test yang di dapatkan siswa yaitu 84,41 sedangkan rata-rata hasil belajar siswa kelas IIIb sebagai kelas kontrol yaitu 70,03. Setelah dilakukan pengujian hipotesis maka hasilnya diperoleh $t_{\text {hitung }}>t_{\text {tabel }}(4,56$ $>2,000$ ), sehingga Ha dapat diterima Ho ditolak. Dengan demikian, Ha dapat diterima berarti ada pengaruh Penerapan Model Group Investigation (GI) dalam mengidentifikasi Cerpen untuk Meningkatkan Kemampuan Membaca Siswa Pada SDN 02 Palembang. Kemudian apabila hasil 
dari pengujian hipotesis Ha diterima, berarti ada Pengaruh Penerapan Model Group Investigation (GI) dalam mengidentifikasi Cerpen untuk Meningkatkan Kemampuan Membaca Siswa Pada SDN 02 Palembang.

\section{KESIMPULAN}

Berdasarkan hasil analisis data maka dapat disimpulkan hasil nilai tes siswa menunjukkan bahwa dari kedua kelas memiliki perbedaan nilai rata-rata, yaitu untuk kelas eksperimen didapatkan nilai rata-rata sebesar 84,41 sedangkan untuk kelas eksperimen didapatkan nilai rata-rata sebesar 70,03. Hipotesis menunjukan bahwa ada pengaruh Penerapan Model Group Investigation (GI) dalam mengidentifikasi Cerpen untuk Meningkatkan Kemampuan Membaca Siswa Pada SDN 02 Palembang. Hal ini dapat dilihat, dimana setelah dilakukan pengujian hipotesis dengan rumus uji-t hasilnya diperoleh $t_{\text {hitung }}>t_{\text {tabel }}(4,56>2,00)$, sehingga Ha dapat diterima, dan Ho ditolak. Dengan demikian, Ha dapat diterima berarti ada pengaruh Penerapan Model Group Investigation (GI) dalam mengidentifikasi Cerpen untuk Meningkatkan Kemampuan Membaca Siswa Pada SDN 02 Palembang.

\section{DAFTAR PUSTAKA}

Aminudin, dkk. 2008. Aktif dan Kreatif Berbahasa Indonesia. Jakarta: Pusat Perbukuan.

Arikunto, Suharsimi. 2014. Prosedur Penelitian. Jakarta: PT Rineka Cipta.

Fathurrohman, Muhammad. 2015. Model-Model Pembelajaran Inovatif. Jakarta: Ar-Ruzz Media.

Kosasih. 2014. Dasar-Dasar Keterampilan Bersastra. Bandung: Cv. Yrama Widya.

Kosasih. 2014. Jenis-Jenis Teks. Bandung: Yrama Widya.

Mulyatiningsih, Endang. 2014. Metode Penelitian Terapan Bidang Pendidikan. Yogyakarta: Alfabeta.

Riduwan. 2013. Belajar Mudah Penelitian. Bandung: Alfabeta. Sugiyono. 2013. Metodelogi Penelitian Pendidikan. Bandung: Alfabeta. 